\title{
Nitrogen Contents in Soil, Grains, and Straw of Hybrid Rice Differ When Applied with Different Organic Nitrogen Sources
}

\author{
Amanullah $^{1}{ }^{1}\left(\mathbb{D}\right.$, Hidayat Ullah ${ }^{1}$, Mohamed Soliman Elshikh ${ }^{2}$, Mona S. Alwahibi ${ }^{2}$ (D), \\ Jawaher Alkahtani $^{2}$, Asim Muhammad ${ }^{1}{ }^{1}$, Shah Khalid ${ }^{1}$ and Imran ${ }^{1} \mathbb{D}$ \\ 1 Department of Agronomy, Faculty of Crop Production, The University of Agriculture, \\ Peshawar 25130, Pakistan; hidayat088@gmail.com (H.U.); asimmuh@aup.edu.pk (A.M.); \\ khalidmashaal@aup.edu.pk (S.K.); imranagrarian@aup.edu.pk (I.) \\ 2 Department of Botany and Microbiology, College of Science, King Saud University, \\ Riyadh 11451, Saudi Arabia; melshikh@ksu.edu.sa (M.S.E.); malwhibi@ksu.edu.sa (M.S.A.); \\ jsalqahtani@ksu.edu.sa (J.A.) \\ * Correspondence: amanullah@aup.edu.pk; Tel.: +92-300-5741363
}

Received: 25 July 2020; Accepted: 29 August 2020; Published: 2 September 2020

\begin{abstract}
In the rice-wheat (R-W) system, inorganic nitrogen (N) fertilizer (urea, etc.) is the largest component of the $\mathrm{N}$ cycle, because the supply of $\mathrm{N}$ from organic fertilizers is insufficient. But the $4 \%$ Initiative aims to improve organic matter and stimulate carbon sequestration in soils using best agronomic practices (sustainable management practices) which are economically, environmentally, and socially friendly. This research project was, therefore, designed to assess the impact of various organic sources (OS, animal manure versus plant residues), inorganic N (urea), and their different combinations on the $\mathrm{N}$ concentrations in soils and plants (i.e., grains and straw) of hybrid rice plants. The experiments were conducted on farmers' fields in Batkhela (Malakand), northwestern Pakistan, over 2 years (2011-2012 (Y1) and 2012-2013 (Y2)). The results revealed that $\mathrm{N}$ concentrations in soil as well as in rice plants ranked first when applied with urea-N, followed by the application of $\mathrm{N}$ in mixture (urea + OS), while the control plots (no N applied) ranked at the bottom. Among the six OS (three animal manures: poultry, sheep, and cattle; and three crop residues: onion, berseem, and wheat), application of $\mathrm{N}$ in the form of poultry manure was superior in terms of higher $\mathrm{N}$ concentrations in both soil and plants. Applying the required total $\mathrm{N}\left(120 \mathrm{~kg} \mathrm{~N} \mathrm{ha}^{-1}\right)$ in the form of $75 \% \mathrm{~N}$ from urea $+25 \% \mathrm{~N}$ from OS resulted in higher $\mathrm{N}$ concentrations in soil and plants in $\mathrm{Y} 1$. The required total $\mathrm{N}\left(120 \mathrm{~kg} \mathrm{~N} \mathrm{ha}^{-1}\right)$ application in the form of $50 \% \mathrm{~N}$ from urea $+50 \% \mathrm{~N}$ from OS produced higher $\mathrm{N}$ concentrations in soil and plants in $\mathrm{Y} 2$. It was concluded from the results, that combined application of $\mathrm{N}$ sources in the form of urea + OS can produce good performances in terms of higher $\mathrm{N}$ concentrations in soil as well as in rice plants under the $\mathrm{R}-\mathrm{W}$ system. Integrated use of urea (N-fertilizer) with organic carbon sources (animal manures and crop residue) could sustain rice-based (exhaustive) cropping system.
\end{abstract}

Keywords: rice; organic source; urea; nitrogen; ratio; $\mathrm{N}$ concentration in soil; $\mathrm{N}$ concentration in rice plants

\section{Introduction}

Rice (Oryza sativa L.) and wheat (Triticum aestivum L.) are the two most commercially important crops, accounting for more than $40 \%$ of world food production. Farmers in Asia have been using the $\mathrm{R}-\mathrm{W}$ system for more than 1000 years. Continuous cultivation of $\mathrm{R}-\mathrm{W}$ system has resulted in an increase in nutrient mining and a decrease in yields of both crops [1]. The $\mathrm{R}-\mathrm{W}$ crop-system is extremely nutrient-exhaustive and, thus, its continuous use has decreased soil fertility, leading to 
nutrient deficiency [1-3]. Rice is very important food human and contribute about $35-60$ of the dietary calories for almost 3 billion people [4]. The irrigated lowland rice system accounts for approximately $55 \%$ of the worlds harvested rice area and contributes approximately $76 \%$ of global rice production [4]. In contrast to wheat, $95 \%$ of the world's rice is grown in less developed nations, mainly in Asia, Africa, and Latin America. China and India are the world's largest developing and consuming rice production countries. By 2025, it is projected that about $60 \%$ more rice will have to be produced to meet the food needs of a growing world population. Rice is Asia's principal staple meal. By 2030, the world's demand for milled rice is expected to be around 533 million tons. The rice-wheat (R-W) rotation is the most important crop rotation system in Southern and Eastern Asia, with an estimated area of 21.9 million hectares in seven countries: Bangladesh, Bhutan, China, India, Myanmar, Nepal, and Pakistan [5]. Reference [6] indicates that rice and wheat yields have reached a plateau in the Indo-Gangetic plains region of four South Asian countries, namely, India, Pakistan, Nepal, and Bangladesh due to the decline in soil fertility [7-9] under a continuous $\mathrm{R}-\mathrm{W}$ cropping system $[2,8,10]$. It is important to analyze the effects of $\mathrm{R}-\mathrm{W}$ cropping systems on long-term sustainability and to compare the conventional practice of chemical fertilizers with the integrated use of organic manures $[1,2,8]$. Long-term studies are required to understand various plant, soil, climatic, and agronomic interactions and their effects on crop productivity [11-13]. The R-W system is considered the backbone of food self-sufficiency; unfortunately, it is faced with the problem of sole chemical fertilizer use without organic manure application [7]. The increased productivity factor and depletion of organic matter (soil organic carbon) and nutrients from soil are the consequences of modern $\mathrm{R}-\mathrm{W}$ production $[3,14,15]$.

Nitrogen is the most limiting nutrient for crop production [5,16]; therefore, efficient use of $\mathrm{N}$ is important for the economic sustainability under the $\mathrm{R}-\mathrm{W}$ system $[17,18]$. The use of adequate $\mathrm{N}$ rates and sources is important for improvement in $\mathrm{N}$ use efficiency [19], reducing production costs and environmental pollution $[19,20]$. The sole use of chemical $\mathrm{N}$-fertilizers without organic sources leads to a gradual decline in soil fertility and lower crop productivity under the R-W system [2,12]. Due to the global energy crisis and the high cost of $\mathrm{N}$ chemical fertilizers (urea, ammonium sulphate, etc.), there is a renewed interest in low-cost alternatives such as the use of organic manures $[1,12,17]$. Complementary use of organic fertilizers is advantageous, and a substantial amount of inorganic $\mathrm{N}$-fertilizer may be saved under the $\mathrm{R}-\mathrm{W}$ system $[7,10,21-25]$. For example, References $[5,7,25]$ reported that application of $\mathrm{N}$ from organic manures increased total soil $\mathrm{N}$ and fertility.

Organic carbon sources include essential plant nutrients (macro and micro) which improve soil properties, increase soil fertility, microbial activities, and crop productivity $[1,10,11]$. Organic sources are considered to be promising renewable, nutrient-rich sources and can be used as a substitute for reducing the cost of chemical fertilizers [22,26-31]. Incorporation of crops residues (CRs) and animal manures (AMs) in soils contribute to increased $\mathrm{N}$ immobilization in crop systems by increasing the amount of $C$ relative to $N$ [1,10,22,32-34]. Organic practices make the $\mathrm{R}-\mathrm{W}$ cropping system more sustainable without adverse effects on natural resources and the environment $[10,16,18,22,35]$. The chemical $\mathrm{N}$-fertilizers on the other hand are very costly and cause environmental issues. Therefore, the use of organic manures (AM versus CR) in field crop production is becoming an ever more important feature of environmentally friendly and sustainable practice $[10,22,28,36]$. Therefore, the use of organic materials (AM and CR) needs to be promoted under the $R-W$ system $[1,10,22]$. The objective of this research project was to investigate the impact of organic carbon sources (animal manures (i.e., cattle, poultry, and sheep) and crop residues (onion, wheat, and berseem)) applied alone or in various combinations with chemical $\mathrm{N}$-source (urea) on rice productivity $[7,10], \mathrm{N}$ concentrations in soil and hybrid rice plants in the current study, and its residual effect on the subsequent wheat crop [8] under the $\mathrm{R}-\mathrm{W}$ cropping system.

\section{Materials and Methods}

Field experiments were conducted to investigate the impacts of organic $\mathrm{N}$ sources (animal manures (AM) and crop residues (CR) and inorganic $\mathrm{N}$ source (urea) management on the nitrogen contents 
in soil, grains and straw of hybrid rice (Pukhraj) and their residual effects on the subsequent wheat (cv. Siren-2010) crop under the R-W system. Six different sources of organic sources (OS) were used: three animal manures-poultry manure (PM), sheep manure (SM) and cattle manure (CM); and three crop residues-onion residues (ORs), berseem residues (BRs), and wheat straw (WS). The C:N ratio of urea was much lower (0.4:1) as compared with CM (19:1), PM (15:1), SM (16:1), OR (15:1), WS (125:1), and BR (20:1). The experiments were carried out on farmers' field in Batkhela, Malakand Division (northwestern Pakistan) during 2011-2012 (Y1) and 2012-2013 (Y2). Batkhela is situated at 71.6167 $\mathrm{E}$ and $34.6167 \mathrm{~N}$ (in decimal degrees) $71^{\circ} 58^{\prime} 17^{\prime \prime} \mathrm{E}$ and or $34^{\circ} 37^{\prime} \mathrm{N}$ (in degrees-minutes-seconds). The soil is moderately calcareous in nature $(\mathrm{CaCO} 3=7.18 \%)$, slightly alkaline $(\mathrm{pH}=7.3)$, clay loam by texture, non-saline $(\mathrm{ECe}=1.02 \mathrm{dS} / \mathrm{m})$, low in soil fertility containing less organic matter $(0.71 \%)$, total $\mathrm{N}(0.51 \%)$, extractable $\mathrm{P}\left(5.24 \mathrm{mg} \mathrm{kg}^{-1}\right)$, exchangeable potassium (AB-DTPA) $\left(71 \mathrm{mg} \mathrm{kg}^{-1}\right)$, and $\mathrm{Zn}$ $\left(0.93 \mathrm{mg} \mathrm{kg}^{-1}\right)$.The OSs were applied 30 days before transplanting, while the urea (chemical $\mathrm{N}$ ) was applied in two equal splits: $50 \%$ at transplanting and $50 \%$ at 30 days after transplanting. In Y1, rice nursery was grown on 4 June 2011, and then the 25 day old seedlings were transplanted on 29 June 2011. In Y2, the rice nursery was grown on 11 June 2011, and then the 25 day old seedlings were transplanted on 5 July 2011. A uniform basal dose of $60 \mathrm{~kg} \mathrm{P} \mathrm{ha}^{-1}$ (as triple super phosphate) and 60 $\mathrm{kg} \mathrm{K} \mathrm{ha}{ }^{-1}$ (as sulphate of potash) were applied uniformly to all plots at the time of transplanting. Nitrogen sources were not applied to the control plots for both years. After the harvest of the rice crop in October, the wheat variety "Siren-2010" was grown in November in both years as a subsequent crop under the $\mathrm{R}-\mathrm{W}$ system.

The experiments were carried out in a randomized complete block design with four replications. The plot size was $12 \mathrm{~m}^{2}(3 \mathrm{~m} \times 4 \mathrm{~m})$ with 300 single plants per plot, and the plant-to-plant distance was $20 \mathrm{~cm}$. All plots were separated by $30 \mathrm{~cm}$ ridges to stop the movement of water/nutrients among different plots (treatments), and water was applied to each plot separately from a water channel. After maturity, $2 \mathrm{~m}^{2}$ of rice within each treatment was harvested, dried, and weighed to calculate biomass [31]. These materials were then threshed, and rice grains were separated and weighed to calculate grain yield [10].

\subsection{Determination of N Content in Soil, Straw, and Grains after Harvesting of Rice Crop}

Soil total $\mathrm{N}(\%)$ was determined calorimetrically. In brief, $0.2 \mathrm{~g}$ of soil/straw/grains was digested in $3 \mathrm{~mL}$ of concentrated $\mathrm{H}_{2} \mathrm{SO}_{4}$ in the presence of $1.1 \mathrm{~g}$ digestion mixture $\left(\mathrm{K}_{2} \mathrm{SO}_{4}, \mathrm{CuSO} 4\right.$, and $\left.\mathrm{Se}\right)$ on block digest for $4-5 \mathrm{~h}$. The temperature was gradually increased up to $3500 \mathrm{C}$ and maintained for $1 \mathrm{hr}$ to appear a light greenish color. After cooling, the digest was transferred to volumetric flask and the volume made up to $100 \mathrm{~mL}$ with distilled water. Then, $20 \mathrm{~mL}$ of the digest was distilled with $5 \mathrm{~mL}$ both of $40 \% \mathrm{NaOH}$ solution and boric acid mixed indicator and titrated against standard $0.005 \mathrm{M} \mathrm{HCl}$. Nitrogen was calculated as $1 \mathrm{~mL}$ of $0.005 \mathrm{M} \mathrm{HCl}$ is equal to $70 \mu \mathrm{g}$. A blank reading was also taken at the same time:

$$
\text { Total N }(\%)=\frac{(\text { sample }- \text { blank }) \times 0.005 \times 0.014 \times 100 \times 100}{\text { Weight of sample } \times 20}
$$

\subsection{Statistical Analysis}

Data on nitrogen contents in soil, grains, and straw of hybrid rice (Pukhraj) were subjected to analysis of variance (ANOVA) according to the methods described for simple randomized complete block design combined over the years [37], and the means in different treatments were compared using the least significant difference (LSD) test $(p \leq 0.05)$. The Statistics v.8.1 (Analytical Software, Tallahassee, FL, USA) was used for the statistical analysis [37]. 


\section{Results}

\subsection{Total Soil Nitrogen after Rice Harvesting}

Organic sources had a significant effect on the total soil nitrogen (TSN) in Y1, Y2, and when combined over the two years' mean data (Table 1). The years' mean data showed PM application produced the highest TSN (776 $\left.\mathrm{mg} \mathrm{kg}^{-1}\right)$, followed by CM (775 $\mathrm{mg} \mathrm{kg}^{-1}$ ), while the minimum TSN (562 $\mathrm{mg} \mathrm{kg}^{-1}$ ) was obtained with use of WS. While, TSN exhibited a non-significant response to $\mathrm{Y} \times$ OS, yet it was higher in Y2 than Y1. In Y1, the TSN ranged between 545 (WS) and $748 \mathrm{mg} \mathrm{kg}^{-1}(\mathrm{CM})$; while in $\mathrm{Y} 2$, it ranged between 580 (WS) and $821 \mathrm{mg} \mathrm{kg}^{-1}$ (PM).

Table 1. Analysis of variance for soil nitrogen concentration $\left(\mathrm{mg} \mathrm{kg}^{-1}\right)$ after harvesting of rice hybrid "Pukhraj" as affected by organic and inorganic fertilizer.

\begin{tabular}{|c|c|c|c|c|c|}
\hline Sources of Variance & Degree of Freedom & Sum of Squares & Mean Squares & F-Values & Significance \\
\hline Years $(\mathrm{Y})$ & 1 & $239,463.00$ & $239,463.00$ & 23.89 & ** \\
\hline Blocks (Years) & 6 & $60,119.96$ & $10,019.99$ & 1.60 & - \\
\hline Treatments & 25 & $1,808,013.00$ & $72,320.51$ & 11.60 & $* * *$ \\
\hline Urea versus Pure OS (Organic Sources) & (1) & $42,508.59$ & $42,508.59$ & 6.82 & ** \\
\hline Among all OS (Sole + Mixtures) & (23) & $1,369,663.00$ & $59,550.57$ & 9.55 & $* * *$ \\
\hline Pure OS vs. Mixtures & $<1>$ & $173,510.40$ & $173,510.40$ & 27.84 & $* * *$ \\
\hline Pure OS & $<5>$ & $345,009.40$ & $69,001.87$ & 11.07 & $* * *$ \\
\hline Ratios & $\{2\}$ & $125,548.20$ & $62,774.10$ & 10.07 & $* * *$ \\
\hline Organic Sources in Mixtures & $\{5\}$ & $700,659.20$ & $140,131.80$ & 22.48 & $* * *$ \\
\hline Ratios $\times$ Organic Sources & $\{10\}$ & $24,935.90$ & 2493.59 & 0.40 & ns \\
\hline $\mathrm{Y} \times$ Treatments & 25 & $144,057.00$ & 5762.28 & 0.92 & ns \\
\hline $\mathrm{Y} \times$ Control vs. rest & (1) & $33,435.13$ & $33,435.13$ & 5.36 & $*$ \\
\hline $\mathrm{Y} \times$ Urea vs. Pure OS & (1) & 136.92 & 136.92 & 0.02 & ns \\
\hline $\mathrm{Y} \times$ Among all OS & (23) & $110,485.00$ & 4803.69 & 0.77 & ns \\
\hline $\mathrm{Y} \times$ Organic Sources in Mixtures & $\{5\}$ & $22,614.72$ & 4522.94 & 0.72 & ns \\
\hline$Y \times$ Ratios $\times$ Organic Sources & $\{10\}$ & $67,778.36$ & 6777.83 & 1.08 & ns \\
\hline Error & 150 & $934,639.10$ & 6230.92 & & \\
\hline Total & 207 & $3,186,292$ & & & \\
\hline
\end{tabular}

$*, * *, * * *$ indicate that data are significant at the $5 \%, 1 \%$ and $0.1 \%$ level of probability, respectively. ns: non-significant data at the $5 \%$ level of probability; () splits of 25 ; <> splits of 23 ; \{\} splits of 17 and 5 degrees of freedom (DF). $\mathrm{CV}=10.98$.

The ratios in $\mathrm{Y} 1, \mathrm{Y} 2$, and the two years' mean had a substantial effect, while the years' $\times$ ratios $(\mathrm{Y} \times \mathrm{R})$ interaction had a non-significant effect on the TSN of rice (Table 2). The mean data of the two years revealed that $\mathrm{N}$ application in the ratio of $25 \mathrm{U}: 75 \mathrm{OS}(25 \% \mathrm{~N}$ from urea $+75 \% \mathrm{~N}$ from organic sources) produced a significantly higher TSN (776 mg kg-1), while the lower TSN was observed with 75U:25OS (75\% N from urea $+25 \% \mathrm{~N}$ from organic sources). The $\mathrm{Y} \times \mathrm{R}$ indicated that TSN was significantly higher in both years while using 25U:75OS. 
Table 2. Soil nitrogen concentration $\left(\mathrm{mg} \mathrm{kg}^{-1}\right)$ after harvesting of rice hybrid "Pukhraj" as affected by organic and inorganic N-fertilizer.

\begin{tabular}{|c|c|c|c|}
\hline N Source & 2011 & 2012 & Mean \\
\hline Cattle Manure & 748 & 803 & 775 \\
\hline Poultry Manure & 731 & 821 & 776 \\
\hline Sheep Manure & 664 & 789 & 726 \\
\hline Onion leaves & 586 & 618 & 602 \\
\hline Wheat Straw & 545 & 580 & 562 \\
\hline Berseem Straw & 603 & 653 & 628 \\
\hline Level of Significance & $* * *$ & $* * *$ & $* * *$ \\
\hline 75U:25OS & 678 & 737 & 707 \\
\hline 50U:50OS & 720 & 800 & 760 \\
\hline 25U:75OS & 731 & 821 & 776 \\
\hline Level of Significance & * & $* *$ & $* * *$ \\
\hline Urea + Organic sources & & & \\
\hline Urea + Cattle Manure & 748 & 851 & 800 \\
\hline Urea + Poultry Manure & 751 & 863 & 807 \\
\hline Urea + Sheep Manure & 783 & 835 & 809 \\
\hline Urea + Onion Leaves & 705 & 777 & 741 \\
\hline Urea + Wheat Straw & 577 & 649 & 613 \\
\hline Urea + Berseem Straw & 695 & 739 & 717 \\
\hline Level of Significance & $* * *$ & $* * *$ & $* * *$ \\
\hline \multicolumn{4}{|c|}{ Planned Mean Comparison } \\
\hline Control & 530 & 471 & $501 \mathrm{~b}$ \\
\hline Rest & 684 & 756 & $720 \mathrm{a}$ \\
\hline Urea & 624 & 688 & $656 \mathrm{~b}$ \\
\hline Mixture & 710 & 786 & $748 \mathrm{a}$ \\
\hline Pure OS & 646 & 711 & $678 \mathrm{~b}$ \\
\hline Mixture & 710 & 786 & $748 \mathrm{a}$ \\
\hline Urea & 624 & 688 & $656 a$ \\
\hline Pure OS & 646 & 711 & $678 \mathrm{a}$ \\
\hline Animal Manure & 749 & 839 & $794 \mathrm{a}$ \\
\hline Crop Residues & 639 & 695 & $667 \mathrm{~b}$ \\
\hline Urea & 624 & 688 & $656 \mathrm{~b}$ \\
\hline Pure OS + Mix & 694 & 767 & $730 \mathrm{a}$ \\
\hline Interactions & Significance & Interactions & Significance \\
\hline $\mathrm{Y} \times \mathrm{OS}$ & $\mathrm{ns}$ & Y $\times$ U vs. Mix & ns \\
\hline $\mathrm{Y} \times$ ratios & $\mathrm{ns}$ & $Y \times$ OS versus Mix & ns \\
\hline$Y \times$ mixtures & ns & $\mathrm{Y} \times \mathrm{AM}$ versus $\mathrm{CR}$ & ns \\
\hline $\mathrm{Y} \times$ control versus rest & * & $\begin{array}{c}\mathrm{Y} \times \mathrm{U}_{\operatorname{Mix}}^{\mathrm{versus}} \mathrm{OS}+ \\
\end{array}$ & ns \\
\hline $\mathrm{Y} \times$ urea versus OS & ns & & \\
\hline
\end{tabular}

$*, * * * * *$ indicate that data are significant at the $5 \%, 1 \%$ and $0.1 \%$ level of probability, respectively. ns: non-significant data at the $5 \%$ level of probability. Means followed by different letters in the same category are significantly different at the $5 \%$ level of probability.

The mixtures had a significant effect on TSN in Y1, Y2, and the two years' mean, while their interaction $(\mathrm{Y} \times \mathrm{M})$ had a non-significant effect on TSN (Table 2). The TSN ranged from $577(\mathrm{U}+\mathrm{WS})$ to $783 \mathrm{mg} \mathrm{kg}^{-1}(\mathrm{U}+\mathrm{SM})$ in $\mathrm{Y} 1$, and $649 \mathrm{mg} \mathrm{kg}^{-1}(\mathrm{U}+\mathrm{WS})$ to $863 \mathrm{mg} \mathrm{kg}^{-1}(\mathrm{U}+\mathrm{PM})$ in $\mathrm{Y} 2$. The years' mean data indicated that application of $\mathrm{N}$ in the form of $\mathrm{U}+\mathrm{SM}$ resulted in significantly higher TSN (809 $\left.\mathrm{mg} \mathrm{kg}^{-1}\right)$, followed by U + PM $\left(807 \mathrm{mg} \mathrm{kg}^{-1}\right)$, while $\mathrm{U}+\mathrm{WS}$ had the lowest TSN content (613 $\left.\mathrm{mg} \mathrm{kg}^{-1}\right)$. 
The planned mean comparison indicated that the rest plots (average of all $\mathrm{N}$ treated plots) had the higher TSN than control ( $\mathrm{N}$ not applied). The TSN increased by $9.5 \%$ in the rest plots, decreased by $12.5 \%$ in the control plots in the two years lead to a significant year $\mathrm{x}$ control versus rest interaction. Application of sole urea (U) reduced the TSN as compared U + OS mixtures. The TSN increased by $9.4 \%$ in the sole urea plots in $\mathrm{Y} 2$ over $\mathrm{Y} 1$, but in contrast, the TSN increased by $9.5 \%$ in $\mathrm{Y} 2$ over $\mathrm{Y} 1$ in the mix plots that resulted in non-significant year $\times U$ versus mixture interaction. Application of mixtures (U + OS) produced higher TSN than the use of pure OS. The increase in TSN was $9.1 \%$ in $\mathrm{Y} 2$ over $\mathrm{Y} 1$ while using pure OS, but application of mixture increased the TSN by $9.7 \%$ in $\mathrm{Y} 2$ over $\mathrm{Y} 1$ that resulted in non-significant $\mathrm{Y} \times$ OS versus mixture interactions. On the other hand, TSN was significantly higher with application of pure OS than sole urea. The TSN increased by $9.4 \%$ in Y2 than Y1, when sole urea was used, while in the case of pure OS, TSN increased by $9.1 \%$ in Y2 over Y1. Interestingly, TSN was significantly higher with application of AMs as compared with CRs. The TSN increased by $10.7 \%$ in $\mathrm{Y} 2$ over $\mathrm{Y} 1$ when AM was used, while in the case of CR, TSN increased by $8.2 \%$ in Y2 over Y1. The TSN increased with the application of pure OS + mixtures than sole urea. The TSN increased by $9.4 \%$ in $\mathrm{Y} 2$ over $\mathrm{Y} 1$ with sole urea, while in the case of pure OS + mix, TSN increased by $9.6 \%$ in $\mathrm{Y} 2$ over $\mathrm{Y} 1$ (Table 2).

\subsection{Total Nitrogen Concentration in Rice Grains}

Organic sources had a non-significant effect on total $\mathrm{N}$ in rice grains (TNG), in $\mathrm{Y} 1, \mathrm{Y} 2$, when combined over the two years, and their interaction (Table 3). The mean years' data showed that PM produced the highest TNG $(1.54 \%)$, while the lowest TNG $(1.33 \%)$ was produced with WS. Although TNG showed a non-significant response to $\mathrm{Y} \times \mathrm{OS}$, it was relatively higher in $\mathrm{Y} 2$ than $\mathrm{Y} 1$. In $\mathrm{Y} 1$, the TNG ranged between 1.30 (WS) and 1.52\% (PM), but the differences were not significant. In Y2, it was statistically higher while using PM (1.55\%) and lower with WS (1.36\%).

Table 3. Analysis of variance for nitrogen concentration in grains (\%) of rice hybrid "Pukhraj" as affected by organic and inorganic fertilizer.

\begin{tabular}{|c|c|c|c|c|c|}
\hline Sources of Variance & Degree of Freedom & Sum of Squares & Mean Squares & $F$-Values & Significance \\
\hline Years $(Y)$ & 1 & 0.46 & 0.46 & 16.07 & $* *$ \\
\hline Blocks (Years) & 6 & 0.17 & 0.02 & 1.08 & - \\
\hline Treatments & 25 & 8.16 & 0.32 & 12.39 & $* * *$ \\
\hline Urea versus Pure OS (Organic Sources) & (1) & 0.14 & 0.14 & 5.48 & * \\
\hline Among all OS (Sole + Mixtures) & (23) & 1.29 & 0.05 & 2.14 & ** \\
\hline Pure OS versus Mixtures & $<1>$ & 0.34 & 0.34 & 13.17 & $* * *$ \\
\hline Pure OS & $<5>$ & 0.24 & 0.04 & 1.86 & ns \\
\hline Animal Manures (AM) versus Crop Residues (CR) & $\{1\}$ & 0.18 & 0.18 & 6.85 & ** \\
\hline Mixtures & $<17>$ & 0.70 & 0.04 & 1.57 & ns \\
\hline Ratios & $\{2\}$ & 0.00 & 0.00 & 0.08 & ns \\
\hline Organic Sources in Mixtures & $\{5\}$ & 0.68 & 0.13 & 5.18 & $* * *$ \\
\hline Ratios $\times$ Organic Sources & $\{10\}$ & 0.01 & 0.00 & 0.06 & ns \\
\hline $\mathrm{Y} \times$ Treatments & 25 & 0.37 & 0.01 & 0.56 & ns \\
\hline $\mathrm{Y} \times$ Control versus rest & (1) & 0.10 & 0.10 & 4.03 & $*$ \\
\hline$Y \times$ Urea versus Pure OS & (1) & 0.00 & 0.00 & 0.23 & ns \\
\hline $\mathrm{Y} \times$ Among all OS & (23) & 0.26 & 0.01 & 0.43 & ns \\
\hline$Y \times$ Pure OS versus Mixtures & $<1>$ & 0.05 & 0.05 & 2.15 & ns \\
\hline $\mathrm{Y} \times$ Pure OS & $<5>$ & 0.00 & 0.00 & 0.01 & ns \\
\hline $\mathrm{Y} \times \mathrm{AM}$ versus $\mathrm{CR}$ & $\{1\}$ & 5.84 & 5.84 & 2.21 & ns \\
\hline $\mathrm{Y} \times$ Mixtures & $<17>$ & 0.20 & 0.01 & 0.45 & ns \\
\hline $\mathrm{Y} \times$ Ratios & $\{2\}$ & 0.17 & 0.08 & 3.22 & $*$ \\
\hline$Y \times$ Organic Sources in Mixtures & $\{5\}$ & 0.02 & 0.00 & 0.16 & ns \\
\hline $\mathrm{Y} \times$ Ratios $\times$ Organic Sources & $\{10\}$ & 0.01 & 0.00 & 0.04 & ns \\
\hline Error & 150 & 3.95 & 0.02 & & \\
\hline Total & 207 & 13.13 & & & \\
\hline
\end{tabular}

$*, * *, * * *$ indicate that data are significant at the $5 \%, 1 \%$ and $0.1 \%$ level of probability, respectively. ns: non-significant data at the $5 \%$ level of probability; () splits of 25 ; <> splits of 23 ; \{\} splits of 17 and 5 degrees of freedom (DF). $\mathrm{CV}=11.09$.

The interaction of years $\times$ ratios $(Y \times R)$ had a significant effect on TNG, while the ratios in $Y 1, Y 2$, and the average of the two years had a non-significant effect on the TNG of rice (Table 4). The years' mean data indicated that application of $\mathrm{N}$ in the ratios of both 50U:50OS and 25U:75OS produced higher TNG (1.52\%) than 75U:25OS. The $\mathrm{Y} \times \mathrm{R}$ indicated that TNG $(1.50 \%)$ was higher with 75U:25OS 
in Y1, while the TNG was higher while using 25U:75OS in Y2. The TNG increased $12.19 \%, 9.11 \%$, and $2.16 \%$ in $\mathrm{Y} 2$ over $\mathrm{Y} 1$ while using 25U:75OS, 50U:50OS, and 75U:25OS, respectively.

The mixtures in $Y 1$ and $Y 2$ had a significant effect on TNG of rice (Table 4), while the average of two years and interaction of years $\times$ mixtures $(\mathrm{Y} \times \mathrm{M})$ had a non-significant effect. The TNG varied significantly between $1.33 \%(\mathrm{U}+\mathrm{WS})$ to $1.54 \%(\mathrm{U}+\mathrm{PM})$ in $\mathrm{Y} 1$, and between $1.49 \%(\mathrm{U}+\mathrm{WS})$ to $1.68 \%$ $(\mathrm{U}+\mathrm{PM})$ in $\mathrm{Y} 2$. The average of the two years' data indicated that application of $\mathrm{N}$ in the form of $\mathrm{U}+$ PM produced relatively higher TNG (1.61\%), while U + WS produced the lowest TNG $(1.41 \%)$. The $Y$ $x$ Mix indicated that TNG increased with $U+A M$ than $U+C R$ in both years (Table 4). The percent increase in TNG in $\mathrm{Y} 2$ over $\mathrm{Y} 1$ ranged between $6.18-91.20 \%$ while using $\mathrm{U}+\mathrm{AM}$, but the increase in TNG in Y2 over Y1 was 6.42-10.47\%, while using U + CR. The highest increase in TNG $(10.47 \%)$ in Y2 over Y1 was obtained with U + WS as compared with the lowest increase $(6.18 \%)$ with $\mathrm{U}+\mathrm{SM}$.

The planned mean comparison indicated that the rest plots produced significantly higher TNG than the control plots. The TNG increased by $6.23 \%$ in the rest plots in Y2 than Y1. In contrast, in the control plots the TNG decreased by $26.44 \%$ in $Y 2$ than $Y 1$. Application of sole urea produced higher TNG than mixtures (U + OS). The TNG increased by $2.93 \%$ in the sole urea plots in Y2 over Y1. Application of mixtures produced higher TNG than pure OS. The TNG increased with the application of both pure OS and mixtures in Y2 than Y1. However, the increase in TNG was 3.18\% in Y2 over Y1 while using pure OS, but application of mixture increased the TNG by $7.93 \%$ in Y2 over Y1. The TNG was higher with sole urea than pure OS. The TNG increased by $3.18 \%$ in $Y 2$ than Y1 while using pure OS, while in the case of sole urea, the TNG increased by $2.93 \%$ in $Y 2$ over $Y 1$. The TNG was higher with AM than CR. The TNG increased by $6.77 \%$ in $\mathrm{Y} 2$ over $\mathrm{Y} 1$ while using AM, while in the case of $\mathrm{CR}$, the TNG increased by $6.87 \%$ in year over Y1. The TNG increased with the application of sole urea than pure OS + mixtures. The TNG increased by $6.82 \%$ in $\mathrm{Y} 2$ over $\mathrm{Y} 1$ with pure OS + mix, while in the case of sole urea, the TNG increased by $2.93 \%$ in Y2 over year (Table 4).

Table 4. Nitrogen concentration in grains (\%) of rice hybrid "Pukhraj" as affected by organic and inorganic N-fertilizer.

\begin{tabular}{cccc}
\hline N Source & $\mathbf{2 0 1 1}$ & $\mathbf{2 0 1 2}$ & Mean \\
\hline Cattle Manure & 1.45 & 1.51 & 1.48 \\
Poultry Manure & 1.52 & 1.55 & 1.54 \\
Sheep Manure & 1.41 & 1.45 & 1.43 \\
Onion leaves & 1.37 & 1.41 & 1.39 \\
Wheat Straw & 1.30 & 1.36 & 1.33 \\
Berseem Straw & 1.34 & 1.38 & 1.36 \\
\hline Level of Significance & $\mathrm{ns}$ & $\mathrm{ns}$ & $\mathrm{ns}$ \\
\hline 75U:25OS & 1.50 & 1.53 & 1.51 \\
50U: 50OS & 1.45 & 1.59 & 1.52 \\
25U:75OS & 1.43 & 1.62 & 1.52 \\
Level of Significance & $\mathrm{ns}$ & $\mathrm{ns}$ & \\
\hline Urea + Organic sources & & & 1.58 \\
Urea + Cattle Manure & 1.51 & 1.66 & 1.61 \\
Urea + Poultry Manure & 1.54 & 1.68 & 1.54 \\
Urea + Sheep Manure & 1.50 & 1.59 & 1.50 \\
Urea + Onion Leaves & 1.45 & 1.56 & 1.41 \\
Urea + Wheat Straw & 1.33 & 1.48 & 1.47 \\
Urea + Berseem Straw & 1.42 & 1.52 & \\
\hline
\end{tabular}


Table 4. Cont.

\begin{tabular}{|c|c|c|c|}
\hline Level of Significance & * & * & ns \\
\hline \multicolumn{4}{|c|}{ Planned Mean Comparison } \\
\hline Control & 0.63 & 0.51 & $0.56 \mathrm{~b}$ \\
\hline Rest & 1.47 & 1.56 & $1.51 \mathrm{a}$ \\
\hline Urea & 1.61 & 1.66 & $1.63 \mathrm{a}$ \\
\hline Mixture & 1.46 & 1.58 & $1.52 \mathrm{~b}$ \\
\hline Pure OS & 1.40 & 1.44 & $1.42 \mathrm{~b}$ \\
\hline Mixture & 1.46 & 1.58 & $1.52 \mathrm{a}$ \\
\hline Urea & 1.61 & 1.66 & $1.63 \mathrm{a}$ \\
\hline Pure OS & 1.40 & 1.44 & $1.42 \mathrm{a}$ \\
\hline Animal Manure & 1.50 & 1.61 & $1.55 \mathrm{a}$ \\
\hline Crop Residues & 1.38 & 1.49 & $1.43 \mathrm{~b}$ \\
\hline Urea & 1.61 & 1.66 & $1.63 \mathrm{a}$ \\
\hline Pure OS + Mix & 1.44 & 1.55 & $1.49 \mathrm{a}$ \\
\hline Interactions & Significance & Interactions & Significance \\
\hline $\mathrm{Y} \times \mathrm{OS}$ & ns & $Y \times U$ versus Mix & ns \\
\hline $\mathrm{Y} \times$ ratios & * & Y x OS versus Mix & ns \\
\hline $\mathrm{Y} \times$ mixtures & ns & Y x AM versus CR & ns \\
\hline $\mathrm{Y} \times$ control versus rest & $* * *$ & $Y \times U$ versus $O S+M i x$ & ns \\
\hline $\mathrm{Y} \times$ urea versus OS & ns & & \\
\hline
\end{tabular}

$*, * * *$ indicate that data are significant at $5 \%$ and $0.1 \%$ level of probability, respectively. ns: non-significant data at the $5 \%$ level of probability. Means followed by different letters in the same category are significantly different at the $5 \%$ level of probability.

\subsection{Total Nitrogen Concentration in Rice Straw}

Organic sources had a non-significant effect on total nitrogen in straw (TNS) in Y1, Y2, when combined over the two years, and the interaction $(\mathrm{Y} \times \mathrm{OS})$ on rice (Table 5). The two years' mean data revealed that use of PM produced higher TNS $(0.55 \%)$, while the lower TNS $(0.48 \%)$ was obtained with use of WS, while $\mathrm{Y} \times$ OS had no substantial effect on TNS, yet it was relatively higher in $\mathrm{Y} 2$ than Y1. In Y1, the TNS ranged between 0.47 (WS) and $0.52 \%$ (CM and PM), but the differences were non-significant; while in Y2, it was statistically higher with SM $(0.59 \%)$ and lower with WS $(0.49 \%)$.

The ratios in $Y 1, Y 2$, and their interactive effect $(Y \times R)$ had a substantial effect on TNS, while the mean of the two years had no substantial effect on the TNS of rice (Table 6). The two years' mean data showed that $\mathrm{N}$ application in both ratios of $75 \mathrm{U}: 25 \mathrm{OS}$ and $50 \mathrm{U}: 50 \mathrm{OS}$ produced the higher TNS $(0.56 \%)$ than $25 \mathrm{U}: 75 \mathrm{OS}$. The $\mathrm{Y} \times \mathrm{R}$ showed that in $\mathrm{Y} 1$, application of $75 \mathrm{U}: 25 \mathrm{OS}$ ratio, produced higher TNS, but in Y2, the higher TNS was produced by the ratio of $25 \mathrm{U}: 75 \mathrm{OS}$. The NG increased by $21.16 \%$, $11.29 \%$, and $1.48 \%$ in $\mathrm{Y} 2$ over $\mathrm{Y} 1$ while using 25U:75OS, 50U:50OS, and 75U:25OS, respectively. 
Table 5. Analysis of variance for nitrogen concentration in straw (\%) of rice hybrid "Pukhraj" as affected by organic and inorganic fertilizer.

\begin{tabular}{|c|c|c|c|c|c|}
\hline Sources of Variance & Degree of Freedom & Sum of Squares & Mean Squares & F-Values & Significance \\
\hline Years $(Y)$ & 1 & 0.16 & 0.16 & 14.06 & $* *$ \\
\hline Blocks (Years) & 6 & 0.07 & 0.012 & 1.71 & - \\
\hline Treatments & 25 & 0.64 & 0.02 & 3.71 & $* * *$ \\
\hline Urea versus Pure OS (Organic Sources) & (1) & 0.02 & 0.02 & 3.27 & ns \\
\hline Among all OS (Sole + Mixtures) & (23) & 0.32 & 0.01 & 2.04 & $* *$ \\
\hline Pure OS versus Mixtures & $<1>$ & 0.05 & 0.05 & 8.24 & $* *$ \\
\hline Mixtures & $<17>$ & 0.24 & 0.01 & 2.06 & * \\
\hline Ratios & $\{2\}$ & 0.00 & 0.00 & 0.14 & ns \\
\hline Organic Sources in Mixtures & $\{5\}$ & 0.18 & 0.03 & 5.34 & $* * *$ \\
\hline Ratios $\times$ Organic Sources & $\{10\}$ & 0.05 & 0.00 & 0.81 & ns \\
\hline $\mathrm{Y} \times$ Treatments & 25 & 0.28 & 0.01 & 1.62 & * \\
\hline $\mathrm{Y} \times$ Control versus rest & (1) & 0.03 & 0.03 & 4.99 & * \\
\hline $\mathrm{Y} \times$ Mixtures & $<17>$ & 0.23 & 0.01 & 1.96 & $*$ \\
\hline $\mathrm{Y} \times$ Ratios & $\{2\}$ & 0.09 & 0.04 & 6.80 & $* *$ \\
\hline $\mathrm{Y} \times$ Organic Sources in Mixtures & $\{5\}$ & 0.00 & 0.00 & 0.16 & ns \\
\hline $\mathrm{Y} \times$ Ratios $\times$ Organic Sources & $\{10\}$ & 0.13 & 0.01 & 1.90 & $*$ \\
\hline Error & 150 & 1.04 & 0.00 & & \\
\hline Total & 207 & 2.22 & & & \\
\hline
\end{tabular}

$*, * *, * * *$ indicate that data are significant at the $5 \%, 1 \%$ and $0.1 \%$ level of probability, respectively. ns: non-significant data at the $5 \%$ level of probability; () splits of 25; <> splits of 23; \{\} splits of 17 and 5 degrees of freedom (DF). $\mathrm{CV}=15.26$.

The mixtures in $\mathrm{Y} 1$ had a significant effect, while in $\mathrm{Y} 2$, the two years' mean and interaction of years $x$ mixtures $(Y \times M)$ had no substantial effect on TNS of rice (Table 6). The TNS varied between $0.49 \%(\mathrm{U}+\mathrm{WS}$ and $\mathrm{U}+\mathrm{OL})$ and $0.59 \%(\mathrm{U}+\mathrm{PM})$ in $\mathrm{Y} 1$ and between $0.54 \%(\mathrm{U}+\mathrm{WS})$ and $0.67 \%(\mathrm{U}$ $+\mathrm{PM})$ in $\mathrm{Y} 2$. The two years' average data showed that the use of $\mathrm{U}+\mathrm{PM}$ as source of $\mathrm{N}$ produced relatively higher TNS $(0.63 \%)$, while $\mathrm{U}+\mathrm{WS}$ produced the lowest TNS $(0.51 \%)$. The $\mathrm{Y} \times$ mixtures indicated that TNS increased with $U+A M$ than $U+C R$ in both years (Table 6). The percent increase in TNS in $\mathrm{Y} 2$ over $\mathrm{Y} 1$ ranged between $8.72 \%$ and $11.61 \%$ while using $\mathrm{U}+\mathrm{AM}$, but the increase in TNS in $\mathrm{Y} 2$ over $\mathrm{Y} 1$ was $10.87-14.55 \%$ while using $\mathrm{U}+\mathrm{CR}$. The highest increase in TNS (14.55\%) in Y2 over Y1 was obtained with $\mathrm{U}+\mathrm{BS}$ as compared with lowest increase $(8.72 \%)$ with $\mathrm{U}+\mathrm{WS}$.

Rest produced higher TNS than the control as indicated by the planned mean comparison. The TNS increased by $9.78 \%$ in the rest plots in $\mathrm{Y} 2$ over $\mathrm{Y} 1$, in difference in the control plots the TNS decreased by $22.48 \%$ in $Y 2$ than $Y 1$. Application of sole urea was higher in TNS than mixtures. The TNS increased by $3.24 \%$ in the sole urea plots in $\mathrm{Y} 2$ over $\mathrm{Y} 1$, but in contrast, the TNS increased by $11.70 \%$ in $\mathrm{Y} 2$ over $\mathrm{Y} 1$ in the mix plots that lead to a significant interaction of year $\times U$ versus Mix. Application of mixtures had higher TNS than pure OS. The TNS increased with application of both pure OS and mixtures in Y2 than $\mathrm{Y} 1$. However, the increase in TNS was $8.40 \%$ in $\mathrm{Y} 2$ over $\mathrm{Y} 1$ while using pure OS, but application of the mixture increased the TNS by $11.70 \%$ in $\mathrm{Y} 2$ over $\mathrm{Y} 1$ that resulted in non-significant $\mathrm{Y} \times \mathrm{OS}$ versus mixture interactions. The TNS was higher with sole urea than pure OS. The TNS increased by $8.40 \%$ in $\mathrm{Y} 2$ than $\mathrm{Y} 1$ while using pure OS, while in the case of sole urea, the TNS increased by $3.24 \%$ in $\mathrm{Y} 2$ over $\mathrm{Y} 1$ resulting in significant $\mathrm{Y} \times \mathrm{U}$ versus $\mathrm{OS}$ interaction. The TNS was higher with AM than CR. The TNS increased by $10.46 \%$ in $\mathrm{Y} 2$ over $\mathrm{Y} 1$ while using AM, while in the case of CR, the TNS increased by $11.46 \%$ in $\mathrm{Y} 2$ over $\mathrm{Y} 1$. 
Table 6. Nitrogen concentration in straw (\%) of rice hybrid "Pukhraj" as affected by organic and inorganic N-fertilizer.

\begin{tabular}{|c|c|c|c|}
\hline N Source & 2011 & 2012 & Mean \\
\hline 75U:25OS & 0.55 & 0.56 & 0.56 \\
\hline 50U:50OS & 0.53 & 0.60 & 0.56 \\
\hline 25U:75OS & 0.50 & 0.63 & 0.57 \\
\hline Level of Significance & $*$ & * & ns \\
\hline “Cattle Manure & 0.52 & 0.57 & 0.54 \\
\hline Poultry Manure & 0.52 & 0.57 & 0.55 \\
\hline Sheep Manure & 0.50 & 0.59 & 0.54 \\
\hline Onion leaves & 0.51 & 0.54 & 0.52 \\
\hline Wheat Straw & 0.47 & 0.49 & 0.48 \\
\hline Berseem Straw & 0.49 & 0.53 & 0.51 \\
\hline Level of Significance & ns & ns & ns \\
\hline \multicolumn{4}{|l|}{ Urea + Organic sources } \\
\hline Urea + Cattle Manure & 0.54 & 0.59 & 0.57 \\
\hline Urea + Poultry Manure & 0.59 & 0.67 & 0.63 \\
\hline Urea + Sheep Manure & 0.55 & 0.61 & 0.58 \\
\hline Urea + Onion Leaves & 0.49 & 0.58 & 0.54 \\
\hline Urea + Wheat Straw & 0.49 & 0.54 & 0.51 \\
\hline Urea + Berseem Straw" & 0.51 & 0.60 & 0.55 \\
\hline Level of Significance & $* *$ & ns & * \\
\hline \multicolumn{4}{|c|}{ Planned Mean Comparison } \\
\hline Control & 0.40 & 0.32 & $0.36 \mathrm{~b}$ \\
\hline Rest & 0.53 & 0.59 & $0.56 \mathrm{a}$ \\
\hline Urea & 0.60 & 0.62 & $0.61 \mathrm{a}$ \\
\hline Mixture & 0.53 & 0.60 & $0.56 b$ \\
\hline Pure OS & 0.50 & 0.55 & $0.52 \mathrm{~b}$ \\
\hline Mixture & 0.53 & 0.60 & $0.56 \mathrm{a}$ \\
\hline Urea & 0.60 & 0.62 & $0.61 \mathrm{a}$ \\
\hline Pure OS & 0.50 & 0.55 & $0.52 \mathrm{~b}$ \\
\hline Animal Manure & 0.55 & 0.61 & $0.58 \mathrm{a}$ \\
\hline Crop Residues & 0.49 & 0.56 & $0.53 \mathrm{a}$ \\
\hline Urea & 0.60 & 0.62 & $0.61 \mathrm{a}$ \\
\hline Pure OS + Mix & 0.52 & 0.58 & $0.55 \mathrm{~b}$ \\
\hline Interactions & Significance & Interactions & Significance \\
\hline $\mathrm{Y} \times \mathrm{OS}$ & ns & $\mathrm{Y} \times \mathrm{U}$ versus $\mathrm{Mix}$ & * \\
\hline $\mathrm{Y} \times$ ratios & $* *$ & $\mathrm{Y} \times$ OS versus Mix & ns \\
\hline $\mathrm{Y} \times$ mixtures & ns & $\mathrm{Y} \times \mathrm{AM}$ versus $\mathrm{CR}$ & ns \\
\hline $\mathrm{Y} \times$ control versus rest & $*$ & $\mathrm{Y} \times \mathrm{U}$ versus $\mathrm{OS}+\mathrm{Mix}$ & ns \\
\hline $\mathrm{Y} \times$ urea versus OS & * & & \\
\hline
\end{tabular}

\section{Discussion}

\subsection{Nitrogen Concentration in Soil after Rice Harvest}

The residual effect of organic and inorganic $\mathrm{N}$ sources on available $\mathrm{N}$ status revealed that a negative $\mathrm{N}$ content in soil was observed where $\mathrm{N}$ was applied in the form of mineral fertilizer (urea) or in control plot ( $\mathrm{N}$ not applied). In the case of organic sources, higher $\mathrm{N}$ was noted in AM treated plots, while minimum $\mathrm{N}$ concentration was recorded in $\mathrm{CR}$ treated plots. Lower $\mathrm{N}$ concentration was found 
with a ratio of $75 \mathrm{U}: 25 \mathrm{OS}$, while a maximum $\mathrm{N}$ concentration was obtained with $25 \mathrm{U}: 75 \mathrm{OS}$. Application of $\mathrm{U}+\mathrm{AM}$ gave more soil $\mathrm{N}$ than $\mathrm{U}+\mathrm{CR}$. The soil $\mathrm{N}$ status was greater where $\mathrm{N}$ was supplied through organic and inorganic sources of fertilizers [21]. According to References [21-23], application of farm yard manure (FYM) increased soil organic carbon, available nitrogen, phosphorus and potassium (NPK) when compared with control treatment. Reference [38] suggested that the combined application of organic manures and NPK increases maize yield and soil N. References [5,25] reported that application of N from fertilizer, FYM, and poultry litter increased soil total N, and References $[23,28]$ reported that total $\mathrm{N}$ increased in treatment where poultry manure was applied to the previous wheat crop. Similarly, References $[8,28]$ reported that over a period of 20 years with FYM treatment, soil organic matter increased by $80 \%$ compared to only $10 \%$ with NPK. However, from an environmental and agronomic point of view, manure application was not a better strategy compared to NPK fertilization. Reference [8] also came to the conclusion that the residual effect of organic fertilizers on soil fertility. Wheat yield is in the following order: bird droppings + FYM followed by PM, FYM, and no organic sources. Rice yields and nitrogen availability in low-fertility soils have increased over three years of continuous organic fertilization [28]. However, this may depend on the type and amount of organic matter used. The residual effect of organic and inorganic materials on available $\mathrm{N}$ status revealed that a negative $\mathrm{N}$ content in soil was observed where $\mathrm{N}$ was applied in the form of mineral or in control plot. In the case of organic sources maximum $N$ was noted in AM treated plots having low $C N$ ratio (15:1 to 19:1), while minimum $\mathrm{N}$ concentration was recorded in $\mathrm{CR}$ treated plots having higher $\mathrm{CN}$ ratio (15:1 to 125:1). A lower $\mathrm{N}$ concentration was found with a ratio 75U:25OS, while a maximum $\mathrm{N}$ concentration was obtained from 25U:75OS in both years. Application of $\mathrm{U}+\mathrm{AM}$ gave more soil $\mathrm{N}$ than $\mathrm{U}+\mathrm{CR}$. The soil $\mathrm{N}$ status was greater where $\mathrm{N}$ was supplied through organic and inorganic sources of fertilizers [21]. The study suggested the complementary use of organic and inorganic fertilizer is advantageous, and that a substantial amount of inorganic fertilizer may be saved for rice crop by the use of organic manures. Application of FYM increased soil organic carbon and available NPK when compared with control treatment $[21,23]$. Soil fertility-building in organic systems improves soil biological properties which subsequently influences $\mathrm{N}$ availability to crops $[7,16,39,40]$. High $\mathrm{N}$-uptake under treatment where mineral $\mathrm{N}$ and organic $\mathrm{N}$ ratios were 75U:25OS and 50U:50OS N, respectively [24]. Maximum total $\mathrm{N}$ after each crop harvest was found in the treatment where organic sources were applied with low mineral N. This may be due to the greater quantity of organic sources of $\mathrm{N}$ applied. Reference [38] suggested that the combined application of organic manures and NPK increases maize yield and soil N.

\subsection{Nitrogen Concentration in Rice Grains and Straw after Rice Harvest}

Understanding crop nutrient removal can provide important information for soil fertility management by comparing total crop uptake with inputs from all sources [28]. The present results of our study demonstrated that $\mathrm{N}$ concentrations in rice grains and straw was high when mineral $\mathrm{N}$ was applied in the form of urea or in combination with animal manure $(\mathrm{U}+\mathrm{PM})$, while lower $\mathrm{N}$ concentration was noted where $\mathrm{N}$ was not applied or where $\mathrm{N}$ was applied in the form of organic $\mathrm{N}$. Mineral fertilizers provided better plant growth and nutrient intake when grown in one season compared to organic fertilizers [28]. The residual effect of organic and inorganic materials on available $\mathrm{N}$ status revealed that a negative $\mathrm{N}$ content in soil was observed where $\mathrm{N}$ was applied in the form of mineral or in control plot. In the case of organic sources, maximum $\mathrm{N}$ was noted in AM treated plots, while minimum $\mathrm{N}$ concentration was recorded in CR treated plots. The residual effect of FYM with inorganic fertilizers played an important role in the grain yield of the next wheat crop by improving the absorption of NPK [41]. Improving soil fertility in organic systems improves the biological properties of the soil which subsequently affects the availability of nitrogen for crops [7,42]. Reference [24] reported high $\mathrm{N}$-uptake with mineral $\mathrm{N}$ and organic $\mathrm{N}$ ratios than the control. Previous research has shown that compost and manure increase nutrient efficiency by slowly releasing nutrients and reducing nutrient losses $[15,43]$. The addition of organic fertilizers increases nutrient mobilization and soil microbial activity; improve nutrient mobilization and soil microbial activity; it can also help improve 
nutrition as well as the root system of crops. The present results are consistent with the assumptions in References [44,45] which suggested that increasing soil nitrogen levels may have a positive effect on nitrogen uptake in maize. The effect of organic and inorganic $\mathrm{N}$ status revealed that a negative $\mathrm{N}$ content in soil was observed where $\mathrm{N}$ was applied in the form of mineral $\mathrm{N}$. with organic sources maximum $\mathrm{N}$ with $\mathrm{AM}$ treated plots, while minimum $\mathrm{N}$ concentration was recorded in $\mathrm{CR}$ treated plots. Reference [21] reported that lower $\mathrm{N}$ concentration was found with a ratio of 75U:25OS, while maximum $\mathrm{N}$ concentration was obtained with 25U:75OS. Application of $\mathrm{U}+\mathrm{AM}$ resulted in significantly higher soil $\mathrm{N}$ than $\mathrm{U}+\mathrm{CR}$. The soil $\mathrm{N}$ status was greater where $\mathrm{N}$ was supplied through organic and inorganic sources of fertilizers. The study suggested the complementary use of organic and inorganic fertilizer is advantageous and substantial amount of inorganic fertilizer may be saved for rice crop by the use of organic manures. According to References [21,23], FYM application increased the available NPK soil organic carbon content compared to control treatments. Improving soil fertility in organic systems improves the biological properties of the soil, which subsequently affects the availability of nitrogen for crops [7,40]. Likewise, Reference [24] reported high N-uptake under treatment where the mineral N and organic $\mathrm{N}$ ratio was higher $75 \mathrm{U}: 25 \mathrm{OS}$ as compared with 50U:50OS N. The maximum total $\mathrm{N}$ after each crop harvest was found in the treatment where OA were applied with low mineral N. This may be due to the greater quantity of organic sources of $\mathrm{N}$ applied. According to Reference [38], combined application of organic manures and NPK increases maize yield and soil N. Likewise, References $[5,25]$ reported that application of $\mathrm{N}$ from fertilizer, FYM, and poultry litter increased soil total $\mathrm{N}$.

\section{Conclusions}

The $\mathrm{N}$ concentration in rice grains and straw increased with the application of mineral $\mathrm{N}$ or with combination of mineral $\mathrm{N}+$ AMs. The $\mathrm{N}$ concentration in grains and straw was reduced significantly when $\mathrm{N}$ was not applied ( $\mathrm{N}$ control plots). The $\mathrm{N}$ concentration in grains and straw increased significantly with the application of $120 \mathrm{~kg} \mathrm{~N} \mathrm{ha}^{-1}$ in the form of sole urea, and urea + PM. Plants grown in $\mathrm{Y} 2$ had more $\mathrm{N}$ concentration in their grains and straw than in $\mathrm{Y} 1$. The soil $\mathrm{N}$ content after rice harvest was higher in plots where $\mathrm{N}$ was applied in the form of sole (pure) organic sources (pure OS $>$ mixtures $>$ pure urea $>$ control).

Author Contributions: A. designed and supervised the research project, drafted, and revised the manuscript, and H.U. carried out the lab and field studies. J.A., M.S.E., M.S.A., A.M., S.K., and I. checked and reviewed the manuscript. All authors have read and agreed to the published version of the manuscript.

Funding: This study was supported by the Higher Education Commission (HEC) of Pakistan, Islamabad (No. 106-1529-AV6-060).

Acknowledgments: We are very grateful to Bob Stewart (Director Dryland Agriculture Institute, WTAMU, Texas, USA) and Weijun Zhou (Institute of Crop Science/Agronomy, Zhejiang University, Hangzhou, China) for evaluating and approving Hidayatullah's $\mathrm{PhD}$ as a foreign expert. We are also very grateful to Paigham Shah at The University of Agriculture Peshawar for the statistical analysis of the data. The Higher Education Commission (HEC), Islamabad, which sponsored this project (No. 106-1529-AV6-060), is highly appreciated. The authors extend their appreciation to the Researchers Supporting Project number (RSP-2020/193) King Saud University, Riyadh, Saudi Arabia.

Conflicts of Interest: The authors declare no conflict of interest.

\section{References}

1. Amanullah; Khalid, S.; Imran; Khan, H.A.; Arif, M.; Altawaha, A.R.; Adnan, M.; Fahad, S.; Parmar, B. Organic matter management in cereals based system: Symbiosis for improving crop productivity and soil health. In Sustainable Agriculture Reviews; Springer: Berlin/Heidelberg, Germany, 2019; pp. 67-92. [CrossRef]

2. Hidaytullah; Amanullah. Sources, ratios and mixtures of organic and inorganic nitrogen influence plant height of hybrid rice (Oryza sativa) at various growth stages. EC Agric 2015, 2, 328-337.

3. Zia, M.S.; Ali, A.; Aslam, M.; Baig, M.; Mann, R. Fertility issues and fertilizer management in rice wheat system. In Farm Research Notes for Asia and Far East; FAO: Roma, Italy, 1997; pp. 36-50. 
4. Fageria, N.K. Dry Matter Yield and Nutrient Uptake by Lowland Rice at Different Growth Stages. J. Plant Nutri. 2004, 27, 947-958. [CrossRef]

5. Mann, R.; Garrity, D. Green manures in rice-wheat cropping systems in Asia. In Green Manure Production Systems for Asian Ricelands: Selected papers from the International Rice Research Conference; Ladha, J.K., Garrity, D.P., Eds.; International Rice Research Institute: Los Banos, Philippines, 1994; pp. $27-42$.

6. Amanullah; Iqbal, A.; Ali, A.; Fahad, S.; Parmar, B. Nitrogen source and rate management improve maize productivity of smallholders under semiarid climates. Front. Plant Sci. 2016, 7, 1773. [CrossRef] [PubMed]

7. Amanullah; Hidayatullah; Jan, A.; Shah, Z.; Khan, M.J.; Parmar, B.; Fahad, S. Organic carbon sources and nitrogen management improve biomass of hybrid rice (Oryza sativa 1.) under nitrogen deficient condition. In Advances in Rice Research for Abiotic Stress Tolerance; Elsevier: Amsterdam, The Netherlands, 2019; pp. 447-467.

8. Hidayatullah; Amanullah; Jan, A.; Shah, Z. Residual effect of organic nitrogen sources applied to rice on the subsequent wheat crop. Int. J. Agron. Plant Prod. 2013, 4, 620-631.

9. Amanullah; Khattak, R.A.; Khalil, S.K. Plant Density and Nitrogen Effects on Maize Phenology and Grain Yield. J. Plant Nutr. 2009, 32, 246-260. [CrossRef]

10. Amanullah; Hidayatullah. Influence of Organic and Inorganic Nitrogen on Grain Yield and Yield Components of Hybrid Rice in Northwestern Pakistan. Rice Sci. 2016, 23, 326-333. [CrossRef]

11. Yadav, D.; Kumar, A. Long-term effect of nutrient management on soil health and productivity of rice (Oryza sativa)-wheat (Triticum aestivum) system. Indian J. Agron. 2009, 54, 15-23.

12. Amanullah; Khalid, S. Agronomy-Food Security-Climate Change and the Sustainable Development Goals. In Agronomy-Climate Change \& Food Security; IntechOpen: Londen, UK, 2020. [CrossRef]

13. Amanullah; Khalid, S.; Khalil, F.; Imranuddin. Influence of irrigation regimes on competition indexes of winter and summer intercropping system under semi-arid regions of Pakistan. Sci. Rep. 2020, 10, 8129. [CrossRef]

14. Panhwar, Q.A.; Ali, A.; Naher, U.A.; Memon, M.Y. Fertilizer Management Strategies for Enhancing Nutrient Use Efficiency and Sustainable Wheat Production. In Organic Farming; Elsevier: Amsterdam, The Netherlands, 2019; pp. 17-39.

15. Amanullah; Khan, A. Phosphorus and compost management influence maize (Zea mays) productivity under semiarid condition with and without phosphate solubilizing bacteria. Front. Plant Sci. 2015, 6, 1083. [CrossRef]

16. Amanullah; Inamullah. Residual phosphorus and zinc influence wheat productivity under rice-wheat cropping system. SpringerPlus 2016, 5, 255. [CrossRef]

17. Fageria, N.K.; Baligar, V.C. Enhancing Nitrogen Use Efficiency in Crop Plants. In Advances in Agronomy; Elsevier: Amsterdam, The Netherlands, 2005; pp. 97-185.

18. Amanullah; Khalid, S. Phenology, growth and biomass yield response of maize (Zea mays L.) to integrated use of animal manures and phosphorus application with and without phosphate solubilizing bacteria. $J$ Microb. Biochem. Technol. 2015, 7, 439-444. [CrossRef]

19. Fageria, N.K.; dos Santos, A.B.; Cobucci, T. Zinc Nutrition of Lowland Rice. Commun. Soil Sci. Plant Anal. 2011, 42, 1719-1727. [CrossRef]

20. Amanullah; Inamullah; Alkahtani, J.; Elshikh, M.S.; Alwahibi, M.S.; Muhammad, A.; Khalid, S. Phosphorus and zinc fertilization improve productivity and profitability of rice cultivars under rice-wheat system. Agronomy 2020, 10, 1085. [CrossRef]

21. Hossaen, M.; Shamsuddoha, A.; Paul, A.; Bhuiyan, M.; Zobaer, A. Efficacy of different organic manures and inorganic fertilizer on the yield and yield attributes of boro rice. Agriculturists 2011, 9, 117-125. [CrossRef]

22. Amanullah; Khan, S.-T.; Iqbal, A.; Fahad, S. Growth and productivity response of hybrid rice to application of animal manures, plant residues and phosphorus. Front. Plant Sci. 2016, 7, 1440.

23. Latt, Y.K.; Myint, A.K.; Yamakawa, T.; Ogata, K. The effects of green manure (Sesbania rostrata) on the growth and yield of rice. J. Fac. Agric. Kyushu Univ. 2009, 54, 313-319.

24. Shah, S.A.; Shah, S.M.; Wisal, M.; Shafi, M.; Haq, N.; Samreen, S.; Amir, M. Effect of integrated use of organic and inorganic nitrogen sources on wheat yield. Sarhad J. Agric. 2010, 26, 559-563.

25. Sahrawat, K. Organic matter and mineralizable nitrogen relationships in wetland rice soils. Commun. Soil Sci.Plant Anal. 2006, 37, 787-796. [CrossRef] 
26. Kumar, V. Nitrogen economy in Indian mustard through use of Azotobacter chroococcum. Crop Res. 1994, 8 , 449-452.

27. Amanullah, K. Maize (Zea mays L.) genotypes differ in phenology, seed weight and quality (protein and oil contents) when applied with variable rates and source of nitrogen. J. Plant. Biochem. Physiol. 2016, 4, 164. [CrossRef]

28. Myint, A.; Yamakawa, T.; Kajihara, Y.; Zenmyo, T. Application of different organic and mineral fertilizers on the growth, yield and nutrient accumulation of rice in a Japanese ordinary paddy field. Sci. World J. 2010, 5. [CrossRef]

29. Nam, M.H.; Jeong, S.K.; Lee, Y.S.; Choi, J.M.; Kim, H.G. Effects of nitrogen, phosphorus, potassium and calcium nutrition on strawberry anthracnose. Plant Pathol. 2006, 55, 246-249. [CrossRef]

30. Manna, M.C.; Ghosh, P.K.; Acharya, C.L. Sustainable crop production through management of soil organic carbon in semiarid and tropical India. J. Sustain. Agric. 2003, 21, 85-114. [CrossRef]

31. Marschner, P. Structure and function of the soil microbial community in a long-term fertilizer experiment. Soil Biol. Biochem. 2003, 35, 453-461. [CrossRef]

32. Leifeld, J.; Angers, D.A.; Chenu, C.; Fuhrer, J.; Katterer, T.; Powlson, D.S. Organic farming gives no climate change benefit through soil carbon sequestration. Proc. Natl. Acad. Sci. USA 2013, 110, E984. [CrossRef]

33. Li, L.; Li, S.-M.; Sun, J.-H.; Zhou, L.-L.; Bao, X.-G.; Zhang, H.-G.; Zhang, F.-S. Diversity enhances agricultural productivity via rhizosphere phosphorus facilitation on phosphorus-deficient soils. Proc. Natl. Acad. Sci. USA 2007, 104, 11192-11196. [CrossRef]

34. Li, M.; Tian, X.-H.; Li, X.-L.; Wang, S.-X. Effect of Zn application methods on Zn distribution and bioavailability in wheat pearling fractions of two wheat genotypes. J. Integr. Agric. 2017, 16, 1617-1623. [CrossRef]

35. Amanullah; Inamullah; Alwahibi, M.S.; Elshikh, M.S.; Alkahtani, J.; Muhammad, A.; Khalid, S.; Imran; Ahmad, M.; Khan, N.; et al. Phosphorus and zinc fertilization improve zinc biofortification in grains and straw of coarse vs. fine rice genotypes. Agronomy 2020, 10, 1155. [CrossRef]

36. Amanullah; Asif, M.; Almas, L.K.; Jan, A.; Shah, Z.; Rahman, H.U.; Khalil, S.K. Agronomic efficiency and profitability of P-fertilizers applied at different planting densities of maize in Northwest Pakistan. J. Plant Nutr. 2012, 35, 331-341. [CrossRef]

37. Steel, R.G.D.; Torrie, J.H.; Deekey, D.A. Principles and Procedures of Statistics: A Biometrical Approach, 3rd ed.; McGraw Hill Book Co. Inc.: New York, NY, USA, 1997.

38. Swarup, A.; Yaduvanshi, N. Effects of integrated nutrient management on soil properties and yield of rice in alkali soils. J. Indian Soc. Soil Sci. 2000, 48, 279-282.

39. Lori, M.; Symnaczik, S.; Mäder, P.; De Deyn, G.; Gattinger, A. Organic farming enhances soil microbial abundance and activity-A meta-analysis and meta-regression. PLoS ONE 2017, 12, e0180442. [CrossRef]

40. Badgley, C.; Moghtader, J.; Quintero, E.; Zakem, E.; Chappell, M.J.; Aviles-Vazquez, K.; Samulon, A.; Perfecto, I. Organic agriculture and the global food supply. Renew. Agric. Food Syst. 2007, 22, 86-108. [CrossRef]

41. Jan, A.; Amanullah; Noor, M. Wheat response to farm yard manure and nitrogen fertilization under moisture stress conditions. J. Plant Nutr. 2011, 34, 732-742. [CrossRef]

42. Amanullah; Inamullah. Dry matter partitioning and harvest index differ in rice genotypes with variable rates of phosphorus and zinc nutrition. Rice Sci. 2016, 23, 78-87. [CrossRef]

43. Khaliq, T.; Mahmood, T.; Masood, A. Effectiveness of farmyard manure, poultry manure and nitrogen for corn (Zea mays L.) productivity. Int. J. Agric. Biol. 2004, 2, 260-263.

44. Haque, M.M.; Hamid, A.; Bhuiyan, N. Nutrient uptake and productivity as affected by nitrogen and potassium application levels in maize/sweet potato intercropping system. Korean J. Crop Sci. 2001, 46, 1-5.

45. Kirkby, E.A.; Bot, J.L.; Adamowicz, S.; Römheld, V. Nitrogen in physiology-an agronomic perspective and implications for the use of different nitrogen forms. In IFS Conference; International Fertiliser Society: York, UK, 2009.

(C) 2020 by the authors. Licensee MDPI, Basel, Switzerland. This article is an open access article distributed under the terms and conditions of the Creative Commons Attribution (CC BY) license (http://creativecommons.org/licenses/by/4.0/). 